Wiraraja Medika : Jurnal Kesehatan
https://www.ejournalwiraraja.com/index.php/FIK
2088-415x (Print)|2685-9998 (online)

\title{
Incidence of infection in wearing contact lenses during covid-19: A Scoping Review
}

Shinta Restu Wibawa

Faculty of Medicine, Public Health and Nursing, Universitas Gadjah Mada,Yogyakarta shinta.r.w@mail.ugm.ac.id

\begin{tabular}{|c|c|}
\hline $\begin{array}{l}\text { INFORMASI } \\
\text { ARTIKEL }\end{array}$ & ABSTRACT \\
\hline $\begin{array}{l}\text { Sejarah artikel: } \\
\text { Received: 05-04-2021 } \\
\text { Revised: 25-05-2020 } \\
\text { Accepted: 20-06-2020 } \\
\text { Keywords: Eye } \\
\text { Infections, } \\
\text { Contac Lenses, } \\
\text { Covid } 19\end{array}$ & $\begin{array}{l}\text { During the Covid-19 pandemic, many people reduced their use of contact } \\
\text { lenses because of eye infections, but also many people continued to use them. } \\
\text { The electronic database scoping review for studies related to Incidence of } \\
\text { infection in wearing contact lenses during covid-19. This study followed the } \\
\text { acronym PCC (P = population; C = concept; C = context). Papers related to the } \\
\text { topic were selected based on their source and publication titles so that } 5 \\
\text { papers were obtained. From the five papers, it was found that the incidence } \\
\text { of eye infections due to using contact lenses in the pandemic era was very } \\
\text { small and low. Some of these studies explained that infections caused, for } \\
\text { example, redness and other symptoms of infection, were not solely due to the } \\
\text { transmission of the Covid-19 virus, but due to other factors such as the lack } \\
\text { of attention of contact lens users on hygiene. It was found that the incidence } \\
\text { of eye infections due to using contact lenses in the pandemic era was very } \\
\text { small and low }\end{array}$ \\
\hline
\end{tabular}

\section{INTRODUCTION}

Contact lenses (CLs) are popular as a refraction correction tool errors for approximately 175 million users worldwide. In 2019, there is data that new lens attachments and repairs were made during the international period. Contact lens prescription survey, 87\%. Although The proportion of standard usage is single-use, but in reality in the field, as much as 55\% of the world's population uses it again (Akerman, 2018). Usable Contac lenses require a number of steps focused on cleaning the lens and maintaining the lens case and everyday wear. as a daily routine is for applying, removing and cleaning lenses which require a high level of hygiene patience (Morgan et al, 2020).

This intricate routine led researchers to conclude that all contact lens wearers do not adhere to some degree due to certain conditions. Non-adherent behavior was associated with an increased risk of CL complications. Signs and symptoms range from reduced comfort and relatively little vision to more serious or potentially threatening inflammation due to infection. Current evidence supports that contact lens (CL) wearers are not at high risk of developing COVID-19 eye-related complications (Hikson,2011).

Contact lens adherence is, at best, a challenging aspect of CL wear, with reported pre-pandemic non-compliance rates ranging from $40 \%$ to $91 \%$ depending on the characteristics of the study sample, modality from lens wear, maintenance and other factors. The coronavirus pandemic (SARS-CoV-2) raised questions at first 2020 about the safety of using CL. This scoping review looks at whether any evidence or evidence is found about indications of an increased risk of contracting COVID-19 through wearing contact lenses.

\section{METHOD}

The electronic database scoping review for studies related to Incidence of infection in wearing contact lenses during covid-19. This study followed the acronym PCC ( $\mathrm{P}=$ population; $\mathrm{C}=$ concept; $\mathrm{C}=$ context). The paper used in the scoping review are obtained through the database provider of the journal Pubmed, Clinical Key, Proquest and Science Direct databases. The author opens the website: sciencedirect. Proquest, email: wiraraja.medika@wiraraja.ac.id 
NCBI, clinicalkey. The researcher wrote the keywords according to the MESH (Medical Subject Heading), namely "Eye Infection", "Contac Lenses", "Covid-19" and full text was selected. Search time from February 2011 to March 2021.

Inclusion criteria for this study: namely: infection in wearing contact lenses during covid-19, the search was carried out for the last 10 years of limitation in the year of publication, full text article / open access, using English, the type of article was a research article, related to the effect of advanced care planning on decisions made by patients about medical actions taken will be done. Paper selection using Endnote X9 and obtained 5 papers that will be synthesized.

\section{RESULTS AND DISCUSSION}

Figure 1 shows the PRISMA flow chart diagram of the study selection process. The first is to select the title. All titles $(n=376)$ and after investigating the same paper, 370 papers were obtained. Papers related to the topic were selected based on their source and publication titles so that 17 papers were obtained. The combinations used in the search terms were checked against the inclusion criteria and finally 5 papers were obtained.

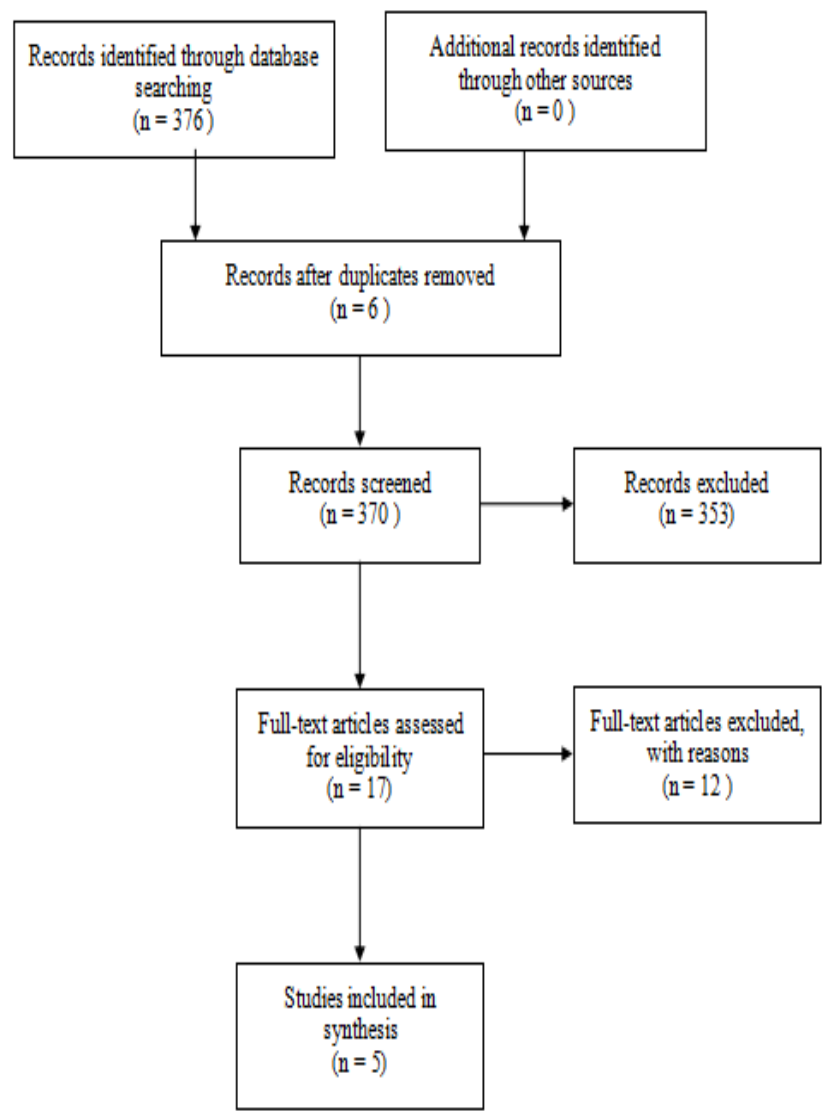

Figure 1. PRISMA Flow Chart Diagram

In this paper, we looked at the incidence of eye infections due to the use of contact lenses from Western and Asian countries. There are 3 papers from western and 2 from ASIA.

\begin{tabular}{|c|c|c|c|c|c|}
\hline No & Author & Title & Method & Western & Incidence of Eye Lens Infections \\
\hline 1 & $\begin{array}{l}\text { Diego et } \\
\text { al } \\
(2020)\end{array}$ & $\begin{array}{l}\text { Influence of the } \\
\text { COVID-19 } \\
\text { pandemic on } \\
\text { contact lens } \\
\text { wear in Spain }\end{array}$ & $\begin{array}{l}\text { Descrip } \\
\text { tive } \\
\text { study }\end{array}$ & $\begin{array}{l}\text { Western } \\
\text { (Spain) }\end{array}$ & $\begin{array}{l}\text { A total of } 737 \text { participants with a mean age of } 27.4( \pm \\
9.3) \text { years completed the online questionnaire. Most of } \\
\text { the respondents were less tired CL users for } 2 \text { years } \\
\text { this. Patient concerns about the increased risk of SARS- } \\
\text { CoV- } 2 \text { infection due to CL use }(40.6 \% \text { of participants) } \\
\text { were significantly associated }(\chi 2(1)=11.195, p<0.05) \\
\text { with discontinuation of CL ( } 46 \% \text { of participants) during } \\
\text { COVID. }-19 \text { pandemics. }\end{array}$ \\
\hline 2 & $\begin{array}{l}\text { May M. } \\
\text { Bakkar } \\
(2021)\end{array}$ & $\begin{array}{l}\text { Assessment of } \\
\text { contact lens } \\
\text { wearers' } \\
\text { attitude toward } \\
\text { contact lens } \\
\text { wear and care } \\
\text { during } \\
\text { Coronavirus } \\
\text { Disease 2019 } \\
\text { (COVID-19) } \\
\text { pandemic: A } \\
\text { cross-sectional } \\
\text { online survey }\end{array}$ & $\begin{array}{l}\text { A } \\
\text { cross- } \\
\text { section } \\
\text { al } \\
\text { online } \\
\text { survey }\end{array}$ & $\begin{array}{l}\text { Asia } \\
\text { (Jordan) }\end{array}$ & $\begin{array}{l}\text { a total of } 196 \text { CL users had completed the online survey } \\
\text { with a mean age of } 26 \text { years }( \pm 4.1) \text { and } 90.8 \% \text { of the } \\
\text { participants were women. based on interviews with } \\
\text { participants, social media is the main source of } \\
\text { information about COVID-19. } 38.8 \% \text { of the study } \\
\text { population reported discontinuing CL use during the } \\
\text { pandemic. The main reason for discontinuation of } \\
\text { lenses is a decrease in social activity during a pandemic. } \\
\text { whereas, in contrast to that, } 61.2 \% \text { of participants } \\
\text { continued wearing lenses, with the majority reporting } \\
\text { large changes in their behavior towards CL use and care } \\
\text { during the pandemic. }\end{array}$ \\
\hline 3 & $\begin{array}{l}\text { Jones et } \\
\text { al } \\
(2020)\end{array}$ & $\begin{array}{l}\text { The COVID-19 } \\
\text { pandemic: } \\
\text { Important } \\
\text { considerations } \\
\text { for contact lens } \\
\text { practitioners } \\
\text { Lyndon Jones }\end{array}$ & $\begin{array}{l}\text { Editoria } \\
l\end{array}$ & $\begin{array}{l}\text { Western } \\
\text { (Canada) }\end{array}$ & $\begin{array}{l}\text { One eye viral infection to consider is epidemic } \\
\text { keratoconjunctivitis (EKC). This disease is transmitted } \\
\text { rapidly through direct contact, accounting for } 65-90 \% \\
\text { of cases of viral conjunctivitis, with a reported } \\
\text { frequency of } 3-15 \% \text { in contact lens wearers. }\end{array}$ \\
\hline
\end{tabular}




\begin{tabular}{|c|c|c|c|c|c|}
\hline 4 & $\begin{array}{l}\text { Raghav } \\
\text { Bhargav } \\
\text { a } \\
(2020)\end{array}$ & $\begin{array}{l}\text { Contact lens } \\
\text { use at the time } \\
\text { of SARS-CoV-2 } \\
\text { pandemic for } \\
\text { healthcare } \\
\text { workers }\end{array}$ & $\begin{array}{l}\text { Additio } \\
\text { nal } \\
\text { article } \\
\text { informa } \\
\text { tion }\end{array}$ & $\begin{array}{l}\text { Asia } \\
\text { (India) }\end{array}$ & $\begin{array}{l}\text { The transmission rate from ocular tissue is suggested } \\
\text { to be low. The frequency of conjunctivitis in patients } \\
\text { with COVID-19 is estimated to be }<3 \text { per cent }\end{array}$ \\
\hline 5 & $\begin{array}{l}\text { Iqbal et } \\
\text { al } \\
(2020)\end{array}$ & $\begin{array}{l}\text { Bilateral Same- } \\
\text { Day Cataract } \\
\text { Surgery: An } \\
\text { Idea Whose } \\
\text { Time Has Come } \\
\text { \#COVID-19 }\end{array}$ & $\begin{array}{l}\text { Editoria } \\
\text { l }\end{array}$ & $\begin{array}{l}\text { Western } \\
\text { (Canada) }\end{array}$ & $\begin{array}{l}\text { There have been a total of } 4 \text { incidents of postoperative } \\
\text { endophthalmitis following unilateral cataract surgery } \\
\text { have been reported in the last } 60 \text { years and all were } \\
\text { due to violation of the aseptic protocol. }\end{array}$ \\
\hline
\end{tabular}

From the five papers, it was found that the incidence of eye infections due to using contact lenses in the pandemic era was very small and low. Some of these studies explained that infections caused, for example, redness and other symptoms of infection, were not solely due to the transmission of the Covid-19 virus, but due to other factors such as the lack of attention of contact lens users on hygiene (Dumbleton,2010). This COVID-19 pandemic shows that some people can be positive and spread the virus agents around asymptomatic or with symptoms (Suprayitno et al, 2020). therefore all medical teams must maintain strict health protocols when examining patients (Bizzoca et al, 2020). Although the prevalence of SARS-CoV-2 is low in tears, it is possible to be transmitted through the eye (Wu, 2020).

Given the transmission of SARSCoV2 through the eye tissue, more studies have been conducted done to ensure its ability to infect eye tissue and tissue pathogenic mechanisms. For example, adherence to poorly reduced hand washing could increase the risk of CL-related infection by $4.5 \mathrm{x}$. whereas there are as many as $50 \%$ of CL users who do not comply with hand washing procedures (Ivan, 2020). Therefore, it is very important to review the steps that contact lens users take each time they wear their lenses. (Morgan, 2020).

Contact lens wearers are less likely to wash their hands, especially using hand washing soap and dry afterwards. especially in the era of the Covid 19 pandemic like this, it is hoped that it will be even tighter to keep the spread of the virus.(CDC, 2009). CL compliance survey in UK and Ireland states that hand washing practices are better in these countries, with $96.0 \%$ of participants using soap and water to clean their hands, although the use of cloth towels is also frequently reported (Wu, 2010).
During the eye exam, face-to-face distance from a slit-lamp biomicroscopic examination can be performed ophthalmologists are at higher risk of exposure to aerosol particles Respiratory droplets and thus contact from health workers who died from COVID-19 in Wuhan, 3 were Chinese ophthalmologists who work in the same unit including Dr. Li Wenliang, who believed he had been infected while nursing asymptomatic glaucoma patients (Olivia Li, 2020). However, the extent of asymptomatic or symptomatic transmission and how much contributing to the pandemic is still unknown (Supinganto et al, 2021)

Health care workers nearly $17 \%$ of the population infected in Poland. Therefore, early identification of infected people is a priority to protect and ensure human resources continued access to surgical care. Both surgical operations, and endoscopic procedures are considered interventions with an increased risk of infection (Murtia et al, 2020). Several infection control measures are practiced universally are recommended, and only a handful of manuscripts have detailed experience gained during the ongoing coronavirus epidemicand previous epidemic outbreaks (Safadi, 2020).

Managing asymptomatic individuals with potential for COVID-19- In areas where SARSCoV is prevalent, all residents should be encouraged to remain alert for symptoms and symptoms. Practice social distancing by staying home as much as possible and keeping a distance of six feet distance (two meters) from other people when they have to leave the house (Kenneth, 2020). Patient education is very important in this regard, given the number of contacts: 1 . Educate for social distancing measures, following Government and Health Authority Instruction. 2. Educate the patient for the correct administration of eye drops 
technique. 3. Educate eyeglass wearers to disinfect and disinfect glasses spectacles. Advance. 4. Wash your hands carefully and thoroughly. 5. Educate contact lens users to wash their hands properly (Veriti et al, 2020).

\section{CONCLUSION}

It was found that the incidence of eye infections due to using contact lenses in the pandemic era was very small and low.

\section{REFERENCE}

Akerman D et al, (2018). The impact of patient behavior and care system compliance on reusable soft contact lens complications. Anter Eye Contact Lens, 41, 319-20.

Center for Disease Control and Prevention (CDC). Keeping hands clean. 2019 (Accessed 21 July 2020, https://www.cdc.gov/healthywater/hygiene /hand/handwashing.html

Dumbleton et al, (2010). Compliance with contact lenses substitutes in Canada and the United States. Optom Vis Sci, 87 (2), 131-9.

Hickson et al, (2011). Attitudes and behavior regarding hygiene and replacement of soft contact lenses and storage cases. Cont Lens Anterior Eye, 11, (34), 207.

Holden BA et al, (2016). Gramnegative bacteria can induce contact lenses related acute red eye (CLARE) responses. CLAO J; 22 (1): 47-52.

Beukes E et al, (2020). Soft contact lens wearers' compliance during the COVID19 pandemic. Anterior Eye Cont Lens. 8 (10), E1180-7.

Morgan et al, (2019). International contact Lens prescribing in 2019. Contact Lens Spectrum, 35, 26-32.

Murtia et al. (2020). Guidelines for the management of surgical departments in non-uniform hospitals during the COVID-19 pandemic. POL PRZEGL CHIR, 92 (2), 42-539, (2), 42-53.

Olivia Li et al. (2020). Readiness Among Ophthalmologists: During and After COVID-19 Pandemic. J Optha, 569-572

Bizzoca et al. (2020).Covid-19 Pandemic: What Changes for Dentists and Oral Medicine Experts? A Narrative Review and Novel Approaches to Infection Containment.Int. J. Environ. Res. Public Health , 17, (3793).

Veriti et al, (2020). Infection control measures in ophthalmology during the
COVID-19 outbreak: A narrative review from an early experience in Italy. EJO, 1-30.

Kenneth, (2020). Coronavirus disease 2019 (COVID-19): Epidemiology, virology, and prevention. https://www.uptodate.com/contents/coron avirus-disease-2019-covid-19-

epidemiology-virology-and-

prevention/print

Safadi et al. (2020). Ophthalmology practice during the COVID-19 pandemic. BMJ Open Ophth (5).

Supinganto, A., Pramana, C., Sirait, L. I., Kumalasari, M. L. F., Hadi, M. I., Ernawati, K., Staryo, N. A., Suprayitno, E., Utami, K., \& Hadi, S. P. I. (2021). The Use of Masks, as an Effective Method in Preventing the Transmission of the COVID-19, During Pandemic and the New Normal Era: A Review. Kusniyati and Hadi, Selasih Putri Isnawati, Review (February 7, 2021).

Suprayitno, E., Rahmawati, S., Ragayasa, A., \& Pratama, M. Y. (2020). Pengetahuan dan Sikap Masyarakat dalam Pencegahan COVID-19. Journal Of Health Science (Jurnal Ilmu Kesehatan), 5(2), 68-73. Ivan. (2020). Can the Coronavirus Disease 2019 (COVID-19) Affect the Eyes? A Review of Coronaviruses and Ocular Implications in Humans and Animals. Ocular Immunology And Inflamation, (28),3: 391-395

Wu et al. (2020). Characteristics of Ocular Findings of Patients With Coronavirus Disease 2019 (COVID-19) in Hubei Province, China. JAMA Opthalmo, 138 (5), 575-57 